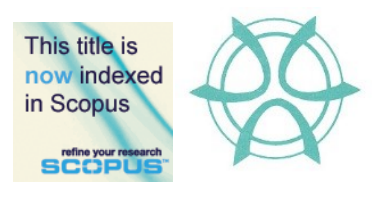

PLANNING MALAYSIA:

Journal of the Malaysian Institute of Planners

VOLUME 19 ISSUE 1 (2021), Page 65 - 76

\title{
COVID-19: B40 HOUSEHOLD'S FINANCIAL AND CONSUMPTION DURING THE IMPLEMENTATION OF MOVEMENT CONTROL ORDER (MCO)
}

\author{
Sharmila Thinagar ${ }^{1,5}$, Siti Nurul Munawwarah Roslan ${ }^{2}$, Mohd Khairi Ismail ${ }^{3}, \&$ \\ Norshamliza Chamhuri ${ }^{4}$ \\ ${ }^{I}$ Faculty of Business and Management \\ QUEST INTERNATIONAL UNIVERSITY \\ ${ }^{2}$ Faculty of Business and Professional Studies \\ MANAGEMENT \& SCIENCE UNIVERSITY (MSU) \\ ${ }^{3}$ Faculty of Business \& Management \\ UNIVERSITI TEKNOLOGI MARA \\ ${ }^{4,5}$ Faculty of Economics \& Management \\ UNIVERSITI KEBANGSAAN MALAYSIA
}

\begin{abstract}
The outbreak of COVID-19 caused the Malaysian Government to take steps to implement the Movement Control Order (MCO). According to Bank Negara Malaysia, the implementation of MCO will have an impact on national incomes, with Malaysia's estimated economic growth in 2020. The effect of MCO not only affects the macro level, but also at the micro level, particularly those groups of households with the lowest income of $40 \%$. (B40). The B40 income group is a group of households that are expected to face high economic risk and directly affect their patterns of consumption during the implementation of the MCO. This study contributes to the empiric study related to COVID-19 and the implementation of MCO in the B40 group. This study analysed the pattern of financial and consumption of B40 households in Malaysia during the implementation of MCO. The findings show that the financial situation of the B40 household has changed the patterns of daily consumption following the implementation of the MCO.
\end{abstract}

Keywords: COVID-19; Movement Control Order (MCO); B40 household; consumption

${ }^{1}$ Lecturer at QUEST University of Perak. Email: sharmila.thinagar@qiup.edu.my 
Sharmila Thinagar, Siti Nurul Munawwarah Roslan, Mohd Khairi Ismail \& Norshamliza Chamhuri COVID-19: B40 Household's Financial and Consumption During the Implementation of Movement Control Order

\section{INTRODUCTION}

The Movement Control Order (MCO) entered into force in Malaysia on 18 March 2020. Although people are depressed, especially those involved in small and medium businesses, the government must extend the MCO period to avoid the risk that the public will be infected with COVID-19 due to sporadic cases or that the public will not be aware that they are infected with the virus. The implementation of MCO has had an impact on household consumption. According to the MCO impact study on households released by the Department of Statistics Malaysia (2020), average consumer spending, excluding financial expenditure, decreased by RM1,923 (48\%) to RM2,110 under MCO. In Malaysia, the household group is categorised into different income groups: bottom $40 \%$ (B40), middle 40\% (M40) and top 20\% (T20). The revenue-based dividing line was used to determine these three groups where the B40 group consists of households earning RM4,360 and below. Meanwhile, households in the M40 and T20 groups are earning RM4,361 - RM9,619 and RM9, 620 and above respectively (Household Expenditure Survey Report 2016). Based on the Department of Statistics Malaysia (2020), the B40 group is the group with the smallest pattern of change in consumption compared to the M40 and T20 groups. This means that the B40 group continues to use it as usual even though MCO is implemented without a reduction in use.

The B40 group is already burdened by rising living costs and the COVID-19 pandemic has added to their anxiety over economic issues such as job security and the development of education for their children. COVID-19 and the implementation of MCO will have an impact on their lives, particularly in the financial and consumer sectors. In terms of income class, the B40 group did not show a significant $41 \%$ difference in the pattern of income consumption compared to the T20 group (59\%) and the M40 group (48\%). This situation shows that the B40 group continues to make the same expenditure and consumption before and after the MCO has been implemented compared to the T20 and M40 groups. Based on the 11th Malaysia Plan Mid-Term Review Report (RMK11), 60\% of B40 household income is spent on basic needs and utilities. For example, for every RM10 they earn, RM6 is spent on needs. So, how can the B40 group lead a normal life during the MCO if their income is affected and they cannot afford to spend on basic goods? Moreover, given that the Malaysian labour market is dominated by almost $60 \%$ of low and medium skills jobs, workers from B40 households are also at risk of losing their jobs and sources of income, and this situation will affect their spending and consumption during the implementation of MCOs. This article therefore discusses and contributes to an empirical study of B40 household financial and consumption analysis during the implementation of the MCO in Malaysia. 
PLANNING MALAYSIA

Journal of the Malaysia Institute of Planners (2021)

\section{LITERATURE REVIEW}

Consumption is the state of expenditure of individuals for the purchase of goods over a given period. According to Mankiw (2000), consumption is a situation in which household goods or services purchased consist of non-durable goods that constitute short-term goods, such as food and clothing, and durable goods that constitute a long-lived product, such as vehicles, televisions, mobile gadgets, mobile phones, etc. Household expenditure is the value of household expenditure on the purchase of several necessities each year. Human behaviour and any changes in consumption patterns have a powerful impact on the environment (Ramli et al. 2019; Kamal et. al., 2020). According to Zainudin et al. (2016), decisions on household expenditure are particularly important for the preservation of the global environment. The money earned by households will be used to purchase food, finance transport utilities, pay children's school fees, pay house rental, and purchase motor vehicles. These items are purchased by the household to meet the requirement, and this spending is referred to as consumption (Yusof et. al., 2019 \& Othman et al. 2020). Domestic purchases, on the other hand, are not all categorised as consumption. When a family purchases a new home, it is classified as an investment. Then there are some of their expenditures that are not classified as consumption, such as paying premiums and sending money to parents (or to studying children), because they are investments made in the economy over the product or service.

In the context of Malaysia, the implementation of the Eleventh Malaysian Plan demonstrates efforts to improve the living standards of the lowest 40\% income group (B40) (MEA, 2019). According to Ghazali (2017), an estimated $64.77 \%$ of B40 households rely on single sources of income, making them vulnerable to shock and stress risks that could theoretically impact their livelihoods. If B40 households continue to be in their current socioeconomic condition, the social cost of the country would be increased by reducing the number of skilled workers needed and thus having an impact on economic growth (Siwar et al. 2015 \& Rashid et al. 2020). The government must therefore implement policies to improve B40 household income. However, as Malaysia continues to expand, B40 households should not be sidelined from enjoying the opportunities that result from the region's growth. It is important to address B40 households, irrespective of ethnicity, particularly poor and low-income households in urban and rural areas, as well as vulnerable households and ambitions. As a result, the role of the Government is not limited to supporting the planning process, but also to implementing and monitoring the process (Mayan, 2017). 
Sharmila Thinagar, Siti Nurul Munawwarah Roslan, Mohd Khairi Ismail \& Norshamliza Chamhuri COVID-19: B40 Household's Financial and Consumption During the Implementation of Movement Control Order

\section{METHODOLOGY}

This study is based on the quantitative study and the non-probability sampling used for the purpose of sampling. The distribution of questionnaires was carried out online (Google form) for the whole of Malaysia between 1 April 2020 and 30 May 2020. Prior to the official distribution of the questionnaires on 1 April, a pilot test was carried out for 10 respondents. For this study, the study population is the B40 income group registered in the Department of Statistics of Malaysia (2020) which was categorised as households earning RM4361 and below. According to Krejcie \& Morgan (1970), if the total population is more than 100,000 , researchers need a total of 384 samples for analysis and it is sufficient to describe the characteristics of the population. In this study, the population of B40 households in Malaysia is 2.78 million, and therefore the study requires at least 384 respondents. However, this study used 504 of the B40 households as a sample study. Descriptive analysis was used to describe the profile of respondents, the financial analysis, and the consumption of B40 respondents. In this study, multiple regressions involve explanatory variables consisting of dependent components and include explanatory variables such as housing loans (X1), personal loans (X2), vehicle loans (X3), credit card payments (X4), business loans (X5), education loans (X6), individual debts (X7) and house rent payments (X8) and the variable criterion (Y) of income of $\mathrm{B} 40$ respondents.

$$
\widehat{Y=} b_{0}+b_{1} X_{1}+b_{2} X_{2}+b_{3} X_{3}+b_{4} X_{4}+b_{5} X_{5}+b_{6} X_{6}+b_{7} X_{7}+b_{8} X_{8}+\mu
$$

Where,

$\hat{Y}=$ dependent variables / income variables

$b=$ regression coefficient for each explanatory variable / independent variable

\section{EMPIRICAL RESULT \\ Profile of Respondent}

The profiles of the study respondents are shown in Table 1. As far as demographics and geography are concerned, the study involved a total of 504 B40 respondents. Most respondents were male (55.2\%) and female (44.5\%). All respondents are households that reside in Malaysia during the MCO implementation period. The states of Selangor and Penang reported the highest percentage of respondents, $25 \%$ and $15.3 \%$ respectively. The Federal Territory of Putrajaya has the lowest percentage of $0.8 \%$ and this percentage corresponds to the small number of B40 in that state. According to the breakdown by region, $65.3 \%$ of respondents live in cities, while the rest live in rural areas. Malays make up the largest percentage of the population, followed by India and China. There are some respondents in this survey who are not from one of the three major races, 
but their percentage is low, at only $6.5 \%$. The percentages by race in this study correspond to Malaysian Statistics records, which show that B40 is made up of Malay, Indian, and Chinese people. As far as the highest level of education is concerned, there are three levels of education with a high percentage of more than $20 \%$, namely bachelor's degree, diploma, and SPM with a total percentage of $71.4 \%$.

Table 1: Profiles of Respondent

\begin{tabular}{|c|c|c|c|}
\hline \multicolumn{4}{|c|}{$\mathrm{n}=504$} \\
\hline Gender & $\%$ & Race & $\%$ \\
\hline Male & 55.2 & Malay & 72.8 \\
\hline Female & 44.8 & Chinese & 9.5 \\
\hline State & & Indian & 11.1 \\
\hline Perlis & 1.4 & Others & 6.5 \\
\hline Kedah & 8.9 & Education Qualification & \\
\hline Penang & 15.3 & Doctor of Philosophy (PhD) & 3.8 \\
\hline Perak & 8.3 & Master & 10.9 \\
\hline Selangor & 25.0 & Bachelor's Degree & 27.0 \\
\hline Johore & 7.9 & Diploma & 20.4 \\
\hline Negeri Sembilan & 1.8 & STPM/Certificate & 6.5 \\
\hline Melaka & 1.4 & SPM/MCE & 24.4 \\
\hline Pahang & 3.2 & $\mathrm{PMR} / \mathrm{SRP}$ & 4.4 \\
\hline Terengganu & 2.8 & UPSR/Completed Standard 6 & 1.0 \\
\hline Kelantan & 6.3 & No education background & 1.6 \\
\hline Sabah & 5.4 & Employment Sector & \\
\hline Sarawak & 2.8 & Government Sector & 24.6 \\
\hline W.P. Labuan & 0.4 & Private Sector & 47.4 \\
\hline W.P. Putrajaya & 0.8 & Self-Employed & 28.0 \\
\hline W.P. Kuala Lumpur & 8.3 & Salary Earning & \\
\hline Area & & Hourly / daily / weekly based & 13.7 \\
\hline Urban & 65.3 & Monthly based & 66.9 \\
\hline Rural & 34.7 & Salary according to demand & 19.4 \\
\hline Age Range & & Monthly Income Range & \\
\hline $18-25$ years & 11.1 & RM580 and below & 7.5 \\
\hline $26-30$ years & 18.5 & RM580 - RM980 & 9.5 \\
\hline $31-40$ years & 41.7 & RM981 - RM2614 & 41.7 \\
\hline $41-60$ years & 26.2 & RM2615 - RM4360 & 41.3 \\
\hline 61 years and above & 2.5 & & \\
\hline
\end{tabular}

This situation shows that most of the respondents had completed high school and had a household income of B40. Economic analysis shows that $47.4 \%$ of respondents work in the private sector and that only $24.6 \%$ in the government sector and $28.0 \%$ of respondents are self-employed. In addition, involvement in 
Sharmila Thinagar, Siti Nurul Munawwarah Roslan, Mohd Khairi Ismail \& Norshamliza Chamhuri COVID-19: B40 Household's Financial and Consumption During the Implementation of Movement Control Order

the employment sector will determine the form of salary earnings. Table 1 shows that there are three forms of salary earnings of study respondents, namely based on hours/day/weekly, monthly and on the request/work performed. Of the three categories, a majority of $66 \%$ earn monthly salaries.

\section{Financial Analysis}

Financial analysis involves the impact of the implementation of MCO in terms of financial and savings resources, the availability of savings, the ability to recover financial resources, the planning to restore financial resources, and action taken in the event of future emergencies such as MCO. Figure 1 shows the impact of MCO implementation on the financial source and the savings of respondents. Most of the respondents argued that the implementation of MCO had an impact on their financial and savings sources. $31.3 \%$ indicated that the implementation of the MCO did not affect their work and salary.

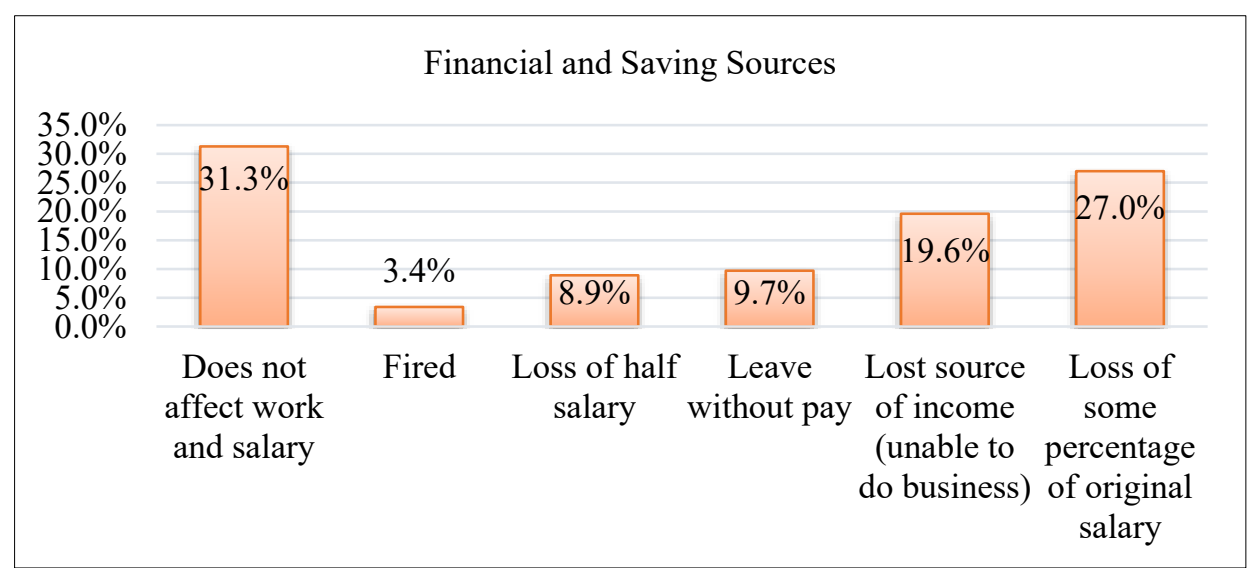

Figure 1: Impact of the implementation of MCO on financial and savings resources Source: Researcher analysis, 2020

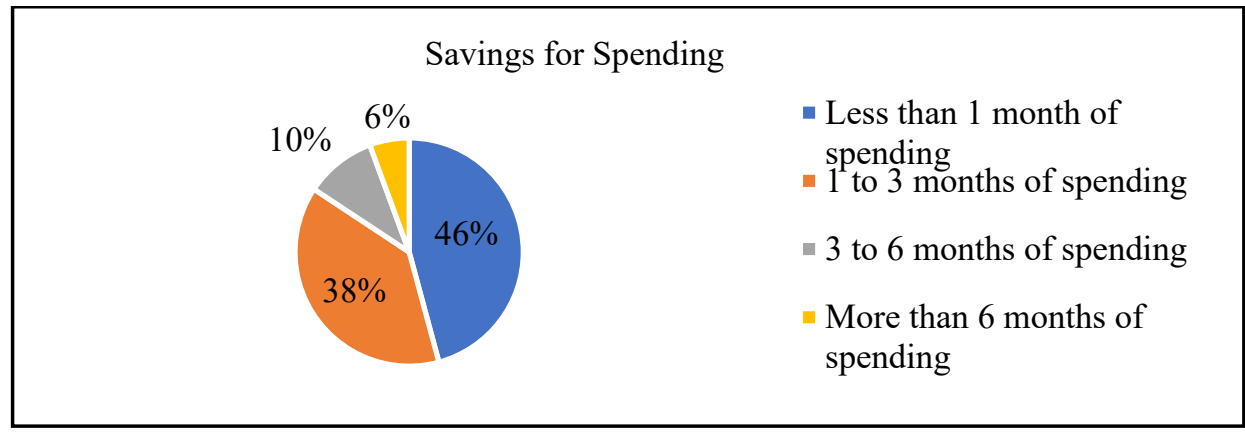

Figure 2: Savings for expenditure in the next six (6) months (June - December 2020) Source: Researcher analysis, 2020 
PLANNING MALAYSIA

Based on the analysis, the respondents experienced a loss of the original salary percentage and a loss of income at a percentage of $27 \%$ and $19.6 \%$, respectively. Respondents who claimed that their salaries were reduced from around $10 \%$ to $20 \%$ because employers from private companies could not afford to pay full salaries. This occurred because all the activities of the company or organisation could not be carried out during MCO and must be put on hold, except for the essential enterprises. Respondents who lose their sources of income are those who have small businesses that cannot carry out business activities during the implementation of MCO and have an impact on their income and consumption during the MCO period. Analysis of respondents' expenditure savings shows that $45.8 \%$ of respondents had savings of less than 1 month of expenditure as shown in Figure 2. In addition, a high percentage also indicates a situation in which $38.5 \%$ of respondents had savings of only 1 to 3 months. Most respondents have less than six months' worth of savings in this situation. If the MCO is in place for more than six months, it will have an impact on the use of respondents, necessitating government assistance. Only 5.6\% of respondents have enough money to last more than six months. Because the characteristics of the B40 group are involved in low-income economic activities, which affects their consumption and savings, the respondents' savings analysis does not reveal an abnormal situation (Chamhuri et. al., 2019).

Table 2 shows that the analysis of the savings held by the respondent's shows that it is for the purchase of basic goods, namely the purchase of food supplies, the payment of utility bills, medicines, and the spending of petrol. However, spending on things like investment and entertainment spending has a lower percentage. This situation shows that B40 households are planning to use their savings to meet basic daily needs. In addition, donations or contributions show $31.9 \%$, which means that the B40 respondents are very focused on welfare issues to help the community. For this section, respondents can give more than one answer based on their purchases and payments, therefore the total percentage cannot be added up to $100 \%$. Respondents also provide some feedback on the issue of their financial ability to recover from the COVID-19 pandemic and the implementation of the MCO. Based on Figure 3, most respondents stated that their finances had recovered within 1 to 6 months. There are $21.4 \%$ of respondents who say they need more than 6 months to recover financially. However, for $5.4 \%$ of respondents, who stated that their finances could not recover, the situation is quite different. According to the findings, the respondents' financial status is important for 1 to 6 months or more. During this time, certain parties should provide support or an incentive to assist the respondent. Deferment of monthly payments (moratorium), tax exemptions, and financial and non-financial assistance are all examples of incentives. Based on a multi-response, $72.4 \%$ reacted to work after the MCO ended and 56.7\% 
Sharmila Thinagar, Siti Nurul Munawwarah Roslan, Mohd Khairi Ismail \& Norshamliza Chamhuri COVID-19: B40 Household's Financial and Consumption During the Implementation of Movement Control Order

respondents planned to add to their source of income to make a living. Some respondents wish to request assistance from families, government and NGOs and obtain credit, but the proportion is small. $85.1 \%$ said they would save money. Some participants plan to diversify their economic resources or their income $(52.2 \%)$ and spend according to their priorities. This situation indicates that respondents are more likely than others to concentrate on savings, income, and cost management aspects because of the implementation of MCO.

Table 2: Sufficient savings for purchases and payments

\begin{tabular}{lc}
\hline Purchases and payments & $\mathbf{\%}$ \\
\hline Buying food supplies & 96.2 \\
\hline Buying medicine supplies & 61.9 \\
\hline Pay off debt & 0.6 \\
\hline Make savings & 17.3 \\
\hline Make an investment & 3.6 \\
\hline Entertainment spending & 3.6 \\
\hline Buying / paying insurance & 17.3 \\
\hline Pay utility bills & 66.1 \\
\hline Pay medical expenses & 14.1 \\
\hline Gasoline spending & 49.4 \\
\hline Online purchase & 25.2 \\
\hline Giving donations / contributions & 31.9 \\
\hline
\end{tabular}

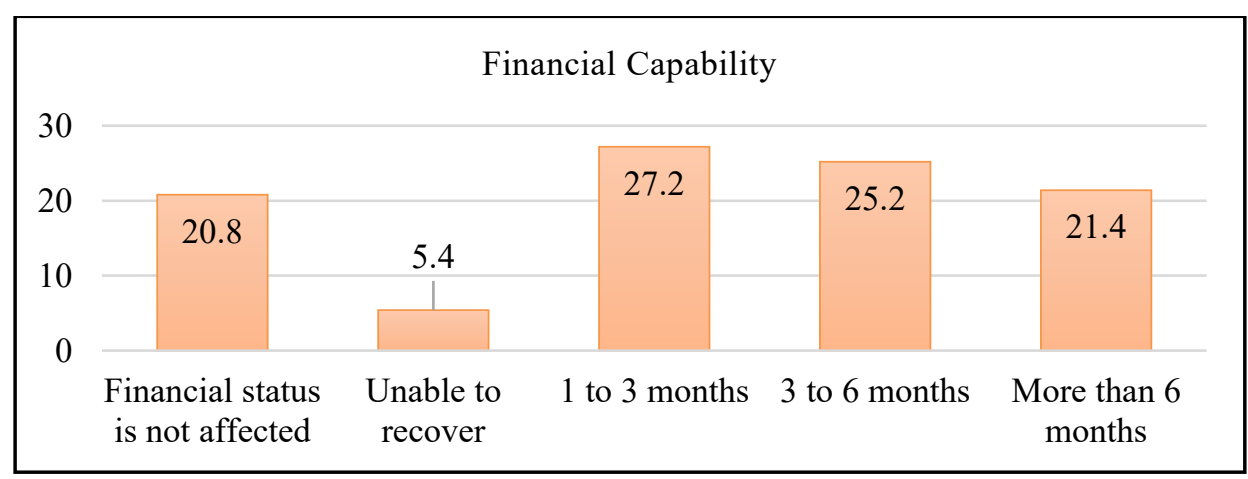

Figure 3: Financial ability to recover.

Source: Researcher analysis, 2020

\section{Consumption Analysis}

Based on Table 4, it shows that the monthly expenses of the respondents depend on the repayment of the loan, individual debt payments and house rent. As the respondent's income falls within B40 household groups, households with lower incomes must support their current income with additional loans and debts to survive on their various types of commitments. Although they work in the private 
sector, their income is lower due to lower levels of education, as shown by $24 \%$ of respondents at the SPM level. There are $8.3 \%$ of respondents who say that they are burdened with any responsibility. In terms of loan liability, the highest percentage of vehicle loans compared to other loans was 43.7\%. Apart from vehicle loans, private loans and housing loans also showed a high percentage of $38.3 \%$ and $28.8 \%$ respectively. Business loans are the lowest percentage because a minority of respondents are self-employed and apply for business loans. In addition, the analysis of respondents' consumption and expenditure involving food supply and purchase frequency showed that $43.8 \%$ of respondents had food supplies during MCO for 1 to 2 weeks, and $19.8 \%$ indicated that they had a food supply resistance of less than one week. This means that if the MCO continues, they will have to go out to increase their food supplies. Ownership of this food supply is influenced by the frequency of food purchases by respondents. The implementation of MCO will inevitably change the percentage of food purchase patterns and food stock storage patterns. The pre-and post-MCO purchase pattern analysis shows the same trend where respondents prefer to purchase food once every two weeks, followed by daily purchases. There are individuals who make purchases once a month, but the percentage is low both before and after MCO. There is, however, a change in the percentage of pre-and post-MCO purchases over four periods.

Table 4: Monthly Expenses

\begin{tabular}{lclc}
\hline Type of liability & $\mathbf{\%}$ & Type of liability & $\mathbf{\%}$ \\
\hline Housing loan & 28.8 & Business loans & 3.4 \\
\hline Personal loan & 38.3 & Education loans & 18.3 \\
\hline Vehicle loans & 43.7 & Individual debt & 13.7 \\
\hline Credit card loans & 8.9 & House rental & 10.7 \\
\hline & & No loans/liability & 8.3 \\
\hline & & \multicolumn{2}{c}{ Source: Researcher } \\
& & &
\end{tabular}

\section{Analysis of income and consumption B40}

The study identified the types of expenditure components that affect the income of B40 households. The determination of consumption factors affecting B40 income was analysed using a multiple regression analysis. The value of $R^{2}$ is 0.757 which indicates that $75.7 \%(\mathrm{r}=0.87)$ of the change in the criterion variable (income) is due to the change in the explanatory variables). Based on Table 5, the significant results show that multiple regression models made up of criterion variables and predictor variables can be generalised to their population. In addition, there are six standard regression coefficients for predictor variables, namely housing loan $[(b=-0.685)$, personal loan $(b=-0.230)$, vehicle loan $(b=-$ $0.297)$, credit card payments $(b=-0.297)$, individual debt $(b=-0.442)$ and house rental payments $(b=-0.494)]$. Since all predictor variable data is dummy, the 
Sharmila Thinagar, Siti Nurul Munawwarah Roslan, Mohd Khairi Ismail \& Norshamliza Chamhuri COVID-19: B40 Household's Financial and Consumption During the Implementation of Movement Control Order

value of each coefficient is in the form of a difference between having and not having dependents. For example, the remaining income difference between those who have a housing loan and those who do not have the loan is 0.685 per RM1 of income.

Table 5: Regression Model

\begin{tabular}{|c|c|c|c|c|}
\hline \multirow[t]{2}{*}{ Model } & \multicolumn{2}{|c|}{ Unstandardised Coefficients } & \multirow[t]{2}{*}{$t$} & \multirow[t]{2}{*}{ Sig. } \\
\hline & $b$ & Standard Error & & \\
\hline Constant & 4.779 & 1.042 & 4.584 & $0.000 *$ \\
\hline Housing loan & -0.685 & 0.095 & -7.242 & $0.000^{*}$ \\
\hline Personal loan & -0.230 & 0.089 & -2.572 & $0.010 * *$ \\
\hline Vehicle loans & -0.297 & 0.087 & -3.414 & $0.000 *$ \\
\hline Credit card payment & -0.225 & 0.095 & -2.368 & $0.010 * *$ \\
\hline Business loans & -0.253 & 0.249 & -1.014 & 0.311 \\
\hline Education loans & -0.124 & 0.120 & -1.032 & 0.302 \\
\hline Individual debt & -0.442 & 0.134 & -3.286 & $0.000 *$ \\
\hline Rental house payment & -0.494 & 0.135 & 3.653 & $0.000 *$ \\
\hline $\mathbf{R}$ & & 0.870 & & \\
\hline R square & & 0.757 & & \\
\hline Adjusted R Square & & 0.754 & & \\
\hline $\mathbf{F}$ & & 11.751 & & \\
\hline Sig. & & 0.000 & & \\
\hline
\end{tabular}

* Significant at 5\%,** Significant at $1 \%$

Dependent Variable $=$ Income; Independent Variable $=$ monthly expenses

\section{POLICY IMPLICATIONS AND RECOMMENDATION}

There are few actions taken by the government to overcome the impact of this pandemic, particularly on the economy, which focus on two policies: first, a moratorium on financial policy and fiscal policy. For fiscal policy, instead of $\mathrm{BPN}$, the government has also issued a Moratorium where all housing loans and car loans can be deferred for six months. This is also part of government initiatives aimed at reducing the burden on those affected and enabling the borrower to have a better financial plan and provide some relief to those struggling with the liquidity crisis. For monetary policy, as a result of the reduction in savings and income of the B40 group, there are few policies that the government can enforce to increase the savings of the B40 group in the future (Ismail et. al., 2019). First, to provide emergency savings plans for B40 groups providing low monthly payments as part of this initiative to encourage more participants for B40 groups. This emergency savings plan will allow them to withdraw their money during the economic downturn or the financial crisis.

\section{CONCLUSION}

In conclusion, the B40 group in Malaysia is the lowest income group to which the government should pay attention. The economic activities of the public and 
the B40 group are the most affected during the period of the COVID-19 pandemic and the implementation of MCO in Malaysia. The key findings of this study showed that more than $70 \%$ of respondents representing the B40 population suffer from decreasing income or job losses. More worryingly, only 5.6\% of respondents save expenses for more than six months. This can cause more urban poverty-related problems such as rising homeless people, increased crime rates and disorders in mental health. The role of the government in supporting these people is therefore very important. We believe that the government's PRIHATIN stimulus package can help Malaysia's B40 group survive in the pandemic of COVID-19 and stimulate economic activity through household consumption expenditure.

\section{REFERENCES}

Department of Statistics Malaysia. (2016). Annual statistics report. Malaysia: Percetakan Nasional.

Department of Statistics Malaysia. (2020). Annual statistics report. Malaysia: Percetakan Nasional.

Ghazali, R. (2017). Keterangkuman dan Masyarakat Saksama: Multi-dimensi Kemudahterancaman Isi Rumah B40 dalam Memperkasa Sosio ekonomi Kelompok B40 Mendepani Arus Perdana. Kuala Lumpur: Institut Tadbiran Awam Negara (INTAN). ISBN: 978-983-3109-95-1.

Household Expenditure Survey 2016. (2017, October 9). Report on Household Expenditure Survey 2016 [Press release]. Retrieved from https://www.dosm.gov.my/v1/index.php?r=column/pdfPrev\&id=WnZvZWNVe DYxKzJjZ3RIUVVYU2s2Zz09.

Ismail, M. K., Siwar, C., Ghazali, R., Ab Rani, N. Z. A., \& Talib, B. A. (2019). The Analysis of Vulnerability Faced by Gahai Agropolitan Participants. Planning Malaysia, 17(2), 249-258.

Kamal, E. M., Lai, K. S., \& Yusof, N. A. (2020). The low-middle income housing challenges in Malaysia. Planning Malaysia, 18(1), 102-117.

Kementerian Hal Ehwal Ekonomi (MEA). (2019). Klasifikasi Pendapatan Isi Rumah Malaysia. Putrajaya. Malaysia.

Khazanah Research Institute (KRI). (2018). The State of Households 2018: Different Realities. October 2018. Perpustakaan Negara Malaysia. ISBN: 978-967-16335$1-9$.

Krejcie, R.V. \& Morgan, D.W. (1970). Determining Sample Size for Research Activities. Educational and Psychological Measurement. 30(3), 607-610.

Mayan, S.N.A. (2017). Challenges to the Household Income Class B40 increase in Developed Country Towards 2020 Case Study: Penang. International Journal of Environment, Society and Space. 5(2), 35-41.

Othman, Z.A., Bakar, A.A., Sani, N.S., \& Sallim, J. (2020). Household Overspending Model Amongst B40, M40 and T20 using Classification Algorithm. International Journal of Advanced Computer Science and Applications. 11(2), 392-399. 
Sharmila Thinagar, Siti Nurul Munawwarah Roslan, Mohd Khairi Ismail \& Norshamliza Chamhuri COVID-19: B40 Household's Financial and Consumption During the Implementation of Movement Control Order

Ramli, N.R., Hashim, E., Jalil, N., Mehdenezhad, M., Leh, F. \& Hashim, A. (2019). The Spending Pattern on Green Products Among Lower Income Group Households in Malaysia. International Journal of Innovation, Creativity and Change. 8(7), 95104.

Rani, N.Z.A., Ghazali, R., Siwar, C., Isa, Z. \& Ismail, M.K. (2019). The Vulnerability Factor Analysis of B40 Household Income Group in Southern Region of Kelantan using Confirmatory Factor Analysis. Academic Journal of Business and Social Sciences. 3, 1-16.

Rashid, N.K.A., Rahizal, N.A. \& Possumah, B.T. (2020). Does Income Difference Cause Different Household Expenditure Consumption? International Journal of Innovation, Creativity and Change. 12(12), 1314-1340.

Rashid, N.K.A., Sulaiman, N.F.C. \& Rahizal, N.A. (2018). Survivability through Basic Needs Consumption among Muslim Households B40, M40 and T20 Income Groups. Pertanika Journal of Social Sciences \& Humanities. 26(2), 985-998.

Sabri, M.F., Mokhtar, N., Ho, C.S.F., Anthony, M. \& Wijekoon, R. (2020). Effects of Gender and Income on Malaysian's Financial Capability. Malaysian Journal of Consumer and Family Economics. 24, 124-152.

Siwar, C., Zahari, S.Z. \& Ismail, M.K. (2015). Kemiskinan dan Agihan Pendapatan di Malaysia: Status dan Kadar Kemiskinan mengikut Etnik dan Strata serta Golongan Berpendapatan Isi Rumah 40 Peratus Terendah (B40). Prosiding Persidangan Kebangsaan Kecemerlangan Melayu II (Ekonomi Melayu). 15-36.

Stiglitz, J. E. (2014). The Price of Inequality: How Today's Divided Society Endangers Our Future. Sustainable Humanity, Sustainable Nature: Our Responsibility:1-21. https://doi.org/10.1080/0305498750010107.

Unit Perancang Ekonomi (EPU). (2015). Jabatan Perdana Menteri, Putrajaya.

World Bank. (2017). Atlas of Sustainable Development Goals 2017: From World Development Indicators. Washington, DC. Retrieved from https://openknowledge.worldbank.org/handle/10986/26306.

Yusof, R. M., Aliyu, S., Khan, S. J. M., \& Majid, N. H. A. (2019). Supply overhang of affordable homes: a survival analysis on housing loans application. Planning Malaysia, 17(1), 250-266.

Zainudin, N., Siwar, C., Choy, E.A. \& Chamhuri, N. (2016). Low-hanging Fruits Impact of Socio-Economic and Behavioral Characteristics on Consumers' Willingness to Pay. Malaysian Journal of Consumer and Family Economics. 9. 115-126.

Received: $4^{\text {th }}$ January 2021. Accepted: $8^{\text {th }}$ March 2021 